\title{
Development Microteaching Handbook for Lecturer, Student, and Learning Laboratory Crew of Science and Mathematic Faculty
}

\author{
Endang Susantini ${ }^{1, *}$, Abdul Kholiq ${ }^{2}$, Bertha Yonata ${ }^{3}$, An Nuril Maulida ${ }^{4}$ \& Ulfi Faizah ${ }^{1}$ \\ ${ }^{1}$ Biology Department, Science and Mathematic Faculty, Surabaya State University, Unesa, \\ Indonesia \\ ${ }^{2}$ Physic Department, Science and Mathematic Faculty, Surabaya State University, Unesa, \\ Indonesia \\ ${ }^{3}$ Chemistry Department, Science and Mathematic Faculty, Surabaya State University, Unesa, \\ Indonesia
}

${ }^{4}$ Science Department, Science and Mathematic Faculty, Surabaya State University, Unesa, Indonesia

*Corresponding author: Biology Department, Science and Mathematic Faculty, Surabaya State University, Unesa, Indonesia. E-mail: endangsusantini@ymail.com

Received: July 3, 2014 Accepted: August 19, 2014 Published: September 29, 2014

doi:10.5296/ije.v6i3.5913ＵRL: http://dx.doi.org/10.5296/ije.v6i3.5913

\begin{abstract}
The purpose of this research is for developing the microteaching handbook for lecturer, student and learning laboratory crew in faculty of science and mathematic. The handbook should be has feasible content. The type of research is development research, there are some steps from this research. First Analysis, second Planning, third Design, fourth Development, and fifth Implementation. Evaluation and Revision include in the research steps and done in any development activities. The point of feasibility handbook review are content, language, performance, and usefulness in supporting innovative learning. The data source from the reviewers who be able indicate that Microteaching Handbook developed properly use in the next implementation of microteaching.
\end{abstract}

Keywords: development, microteaching, handbook, lecturer, student 


\section{Introduction}

Learning micro (micro teaching) is one approach or method to train the teaching performances conducted in a "micro" or simplified. This simplification is related with each component of learning, for example in terms of time, material, number of students, type of teaching basic skills practiced, the use of methods and media, and other elements of learning. There are four essentials elements of learning that has been studied in learning activities: a) the objectives or competencies, b) students need to learn the material, c) methods and media, and d) evaluation. Thus, the simplification in the micro learning, including simplification of the four aspects of learning.

Micro teaching approach as a means of teaching practice, each element of the simplified learning. The simplified form, for example, the normal learning time between 35-45 minutes into a 10-15 minutes, the number of students in the actual conditions faced by some 25-30 people is limited to 5-10 students, teaching basic skills in variety in training only focused on specific skills, such as opening and closing learning skills, or focus on skills using certain methods and media, another basic skill will be trained.

Each pre-service teachers who already practicing or the teachers who already improve basic skills learning through micro, observed and analyzed by supervisors. Observation is intended to identification various the strengths and weaknesses of each participant are practicing. Then feedback forum was held to discuss the strengths and weaknesses with recommendations and solutions for improvement in the next practice. The conclusions are based on the results and recommendations, then the pre service teacher or teachers who practice can repeat the process, until finally obtained maximum proficiency, and so on.

Based on to the process of working through learning how to practice micro teaching briefly illustrated above, that can be formulated in simple language is essentially a micro- learning approach to train pre service teachers and teachers to prepare and improve professionalism through practices in scale simplified. Practice in micro learning is done by controlling, repeating in order to obtain complete to teach basic skills (Sukirman, 2012).

Field Experience is a course that have to master before the student get real teaching or before they teach in partner schools. Field Experience expected to equip the students in designing, implementing and evaluating learning through lectures, simulations, and microteaching. Microteaching is teach in the form of reduced with aim of developing new skills and improve old skills. Student/participants underwent training to teach a small group of students for 5-10 minutes. The microteaching usually recorded by videotape and subsequently observed and analyzed by a student accompanied with lecturer (Brown, 1975; 1991).

In 2012, Surabaya State University in Indonesia, Technical Implementation Unit Field Experience Program already not conducting a microteaching activity, so the Science and Mathematic Learning Laboratory took over these activities. Five programs in the Science and Mathematic Faculty implement microteaching in Learning Laboratory, and successfully implementing shooting and editing 47 pieces of DVD Learning (15 DVD Mathematics study program, 9 DVD Physics study program, 6 DVD Chemical study program, 8 DVD Biological 
study program, and 9 DVD science study program). Learning laboratories are available in Science and Mathematic Faculty has two rooms. First room, where the implementation of microteaching and the second room have the equipment necessary to facilitate crew and teaching practice. The first room is set up as school classrooms, where there are a whiteboard, LCD screens, seating and a table of teachers, as well as seating and student desks. For the amount of seating and student desks in this room is restricted nine tables and chairs. Seating setup also set up so that when the implementation of the practice of teaching, learning lab crew can record all the activities performed. While the second room contains all the equipment for shooting and editing to record the execution of teaching practice, the space between the first and second is dividing walls are made of glass it aims to facilitate communication between the crew is currently recording the practice takes place. Space and learning laboratory facilities in natural science and mathematics faculty still less when compared with the need for practice teaching.

In addition to the facilities, perception of the concept of microteaching practices also need to be considered. It can be seen from the DVD documentation in learning laboratory of activities microteaching (2013) there were emphasizing basic skills teaching and learning model. Therefore, it is necessary to develop microteaching handbook for Field Experience Program lecturers and students so they have same perception about microteaching handbook refers to the way of teaching basic skills, opening skills, closing, explaining, stimulus variation, asked, guiding group discussions, and provide reinforcement. The Handbook is also equipped with instruments basic skills to teach of observation sheets and sample scenarios or learning tools used in microteaching.

Learning Laboratory in science and mathematic faculty has no laboratory or professional crew in carrying out shooting and editing. Crew was obtained from a young lecturer who trained through Microteaching Workshop. Implementation workshop with demonstration method, how to use the tools, how to take pictures, and how to edit images, and then participants were asked to practice the three skills. Weakness workshops that have been conducted is no Microteaching Handbook for Crew. Therefore, in order to be more effective outcomes required workshop Handbook which at any time can be read not only by the crew during the workshop but when the shooting preparation microteaching. Purpose from this research is development microteaching handbook for lecturer, student and learning laboratory crew of science and mathematic faculty.

\section{Methods}

Research to be conducted is development, the research to develop Microteaching Handbook for Lecturers and Students, and Crew learning laboratory.

Step Handbook Microteaching development adopted in this research is the development step by Fenrich (1997). Development guidebook is a systematic process of ongoing activities such 
as the scheme in Figure 1 below.

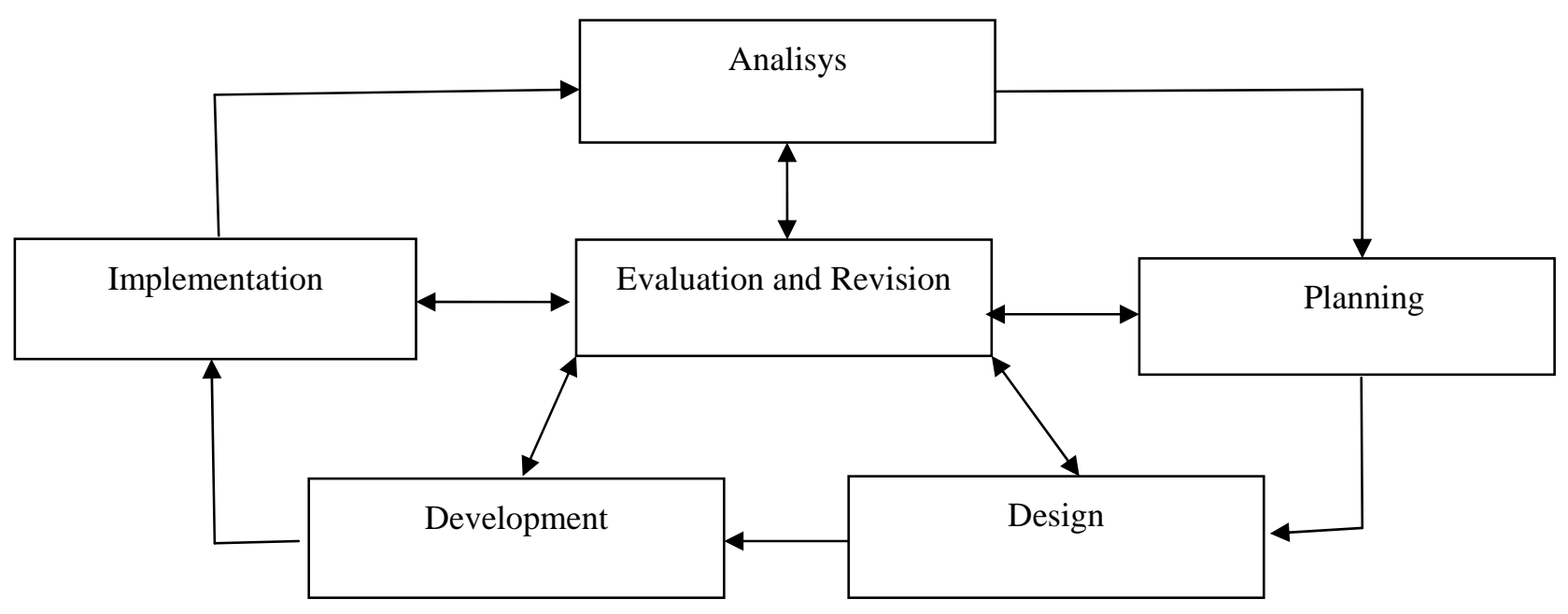

Figure 1. Instructional Development Cycle

Instructional development cycle include phase analysis, planning, design, development, implementation, evaluation and revision. Phase evaluation and revision is an ongoing activity conducted in each phase along the development cycle. So after each phase, that will be evaluated on the results of these activities, then revised according to the results of evaluation, to the next phase (Fenrich, 1997).

In the analysis phase do analyze the undergraduate curriculum in education of Science and Mathematic Faculty and student characteristics. In this phase also the literature study to get an overview of: (a) Education Program Curriculum Mathematics, Physics, Chemistry, Biology, and Science, (b) Microteaching, (c) Handbook. In the phase evaluation and revision are finish.

In the planning phase of the planning done handbook format lecturers, students and learning laboratory Crew. Ding format handbook assessment instrument to measure the feasibility of the book. During this phase of evaluation and revision done.

In the preparation of the Draft design. Microteaching Handbook for Faculty, Students and for Learning laboratory Crew and assessment instruments handbook. Phase evaluation and revision is done.

In the development phase and a review of validation performed Draft Microteaching handbook for lecturers, students and for Learning laboratory Crew. In this phase, activities and a review of validation by expert reviewers media, Mathematics education, and students for legibility. The instrument used to examine the Instrument Textbooks High School (BSNP, 2006). Aspect to consider in reviewing the Handbook are: content, performance, language and readability. Expert reviewers' suggestions and input media, mathematics and science education experts and students used as consideration to evaluate and revise the Handbook. Meanwhile, implementation phase not yet conducted in this study. 


\section{Results and Discussion}

The output research is Handbook of Microteaching. Assessment results Microteaching Handbook presented in Table 1.

Table 1. Assessment Handbook of Microteaching for Lecturers, Student, and Crew

\begin{tabular}{|c|c|c|c|c|}
\hline \multirow[t]{2}{*}{ No. } & \multirow[t]{2}{*}{ Aspect } & \multicolumn{3}{|c|}{ Score } \\
\hline & & V1 & V2 & Mean \\
\hline \multirow{18}{*}{1.} & 1.1 Content & 4 & 4 & 4 \\
\hline & $\begin{array}{l}\text { a. Contents correctness (facts, concepts, principles, } \\
\text { theories }\end{array}$ & & & \\
\hline & b. Contents recency & 4 & 3 & 3.5 \\
\hline & $\begin{array}{l}\text { c. the relevance of material to the needs of users } \\
\text { (lecturer/crew, student) }\end{array}$ & 4 & 3 & 3.5 \\
\hline & $\begin{array}{l}\text { d. Systematically, the corresponding structure of } \\
\text { scientific }\end{array}$ & 4 & 3 & 3.5 \\
\hline & Average of content & & & 3.6 \\
\hline & 1.2 Language & 4 & 3 & 3.5 \\
\hline & $\begin{array}{l}\text { a. Readability language or languages } \\
\text { used in accordance with the user's age } \\
\text { (lecturer/crew, student) }\end{array}$ & & & \\
\hline & b. Indonesian using good and true & 4 & 3 & 3.5 \\
\hline & $\begin{array}{l}\text { c. The term is used appropriately and can be } \\
\text { understood }\end{array}$ & 4 & 4 & 4 \\
\hline & d. Using terms and symbols are consistently & 3 & 4 & 3.5 \\
\hline & Average of Language & & & 3.6 \\
\hline & 1.3 Performance & 4 & 3 & 3.5 \\
\hline & $\begin{array}{l}\text { a. Generating motivation / interest / curiousity } \\
\text { b. In accordance with the level of thinking and } \\
\text { ability to read user (lecturer / crew, student) }\end{array}$ & 4 & 4 & 4 \\
\hline & c. Interesting/fun & 3 & 3 & 3 \\
\hline & d. The clarity of the picture & 3 & 3 & 3 \\
\hline & e. Image supporting content & 4 & 3 & 3 \\
\hline & Average of performance & & & 3.3 \\
\hline \multirow[t]{8}{*}{2.} & Assessment Microteaching Handbook in Supporting & & & \\
\hline & Innovative Learning and Teaching and Learning Quality & & & \\
\hline & Improvement Activities & & & \\
\hline & 2.1 part I (for lecturer and student) & & & \\
\hline & a. Compliance with microteaching concept & & & \\
\hline & & 3 & 4 & 3.5 \\
\hline & $\begin{array}{l}\text { b. Emphasizing on the application of microteaching in } \\
\text { Natural Sciences }\end{array}$ & 4 & 3 & 3.5 \\
\hline & c. To easily develop basic skills teaching & 4 & 4 & 4 \\
\hline
\end{tabular}


No.

d. To easily develop scenarios microteaching

Aspect

Score

e. Sheet observations provide convenience in carrying

out teaching basic skills assessment

Average of Microteaching handbook for lecturer and student

\section{2 part II (for crew)}

a. Makes it easy for beginners to do the shooting

a. The introduction of the tool provides an easy shooting

b. Understanding the learning scenarios to provide convenience in the selection of images

b. The instrument was introduced available in the learning laboratory faculty

c. Makes it easy for beginners to do the editing

$\begin{array}{lll}4 & 4 & 4 \\ 3 & 4 & 3.5 \\ 3 & 3 & 3 \\ 3 & 4 & 3.5 \\ 2 & & \\ 2 & & 2.5\end{array}$

3.3

\section{Comments and Suggestions Improvements}

So that the crew can not perform well editing software introduced alone, but what important is the special training about editing using Pinnacle editing program, for example, with the hardware as well. In Handbook Microteaching for lecturer and students, teaching skills sheet assessment instruments there are 1-5 score. Meanwhile, the book Microteaching for crew image should be adjusted to microteaching activities. In addition, it should be added sub section on wiring, so the novice crew can operate the tool without having to ask.

Every student pre service teachers and for those who have occupied the post of the teaching profession, teaching ability should always be trained and developed, so as to obtain maximum capability and professional. One effort to prepare pre service teacher or the ability to improve the skills of teachers in prepare complex learning tasks, it can be done through a process of training or learning by using models or a more simplified approach to learning referred to micro- learning (microteaching) .

Etymologically, micro teaching is derived from two words namely micro and teaching. Thus, micro teaching can be defined as an activity which is done by teaching simplified or minimized everything. By minimizing the number of students, time, teaching materials and teaching skills specific limit, will be identified various strengths and weaknesses in a potential teacher accurately.

The presence of micro learning (micro teaching) in the curriculum of teacher education programs in 1963. Though long enough, the presence of micro- learning can be considered as an innovation in an effort to prepare and improve the ability or competence of teachers 
compared to the previous condition. Before emerging micro learning approach, each student teachers who have completed a college program that is the theory, to give them practical experience directly to the school for practice teaching, or often called the Field Experience Program.

In the process of learning, teaching skills that include elements of educational value that must be applied by the teacher very much. The ability does not appear, but must be learned, practiced over and over again so that it becomes a positive habit for every teacher in carrying out professional tasks. As to familiarize pre service teachers applying any type of professional teaching basic skills, difficult to control properly done through a process of training or practice activities directly instructing the actual class. Therefore learning micro (micro teaching) can serve as a vehicle for teaching basic skills before teaching in the actual classroom.

From the Table 1, it can be concluded that the assessment valuator microteaching guide book can be used by lecturers Field Experience course and Crew. Although there are aspects of the assessment valuator to "make it easy for the crew to do the editing" still low. But in general guidebook produced can be used as a guide book for the next microteaching implementation. This is in accordance with the criteria for a good book under Government Regulation No. 19 of 2005 and the Ministerial Regulation No. 22 and 23 of 2006 is a book that can be used, both in terms of content as well as physical books, during a period of at least five years. Period of five years is intended to accommodate significant changes in the development of science and technology, and economic considerations in terms of the user (Muljono, 2013).

According to the National Education Standards of Quality Criteria / Standards Textbooks views of the Feasibility Contents / Material; Feasibility Performance; Language feasibility and graph Feasibility. Handbook should have a title, statement, objectives, implementation details, and general information. According to WRI (2013) a few things to consider in preparing a guide book or handbook is to the objective, content, and implementation of an activity. The objectives as follows: (a) What is the main reason the guide book?, (b) For whom the guide book intended?, (c) How does a guidebook or guidelines are used?, (d) What needs to be included in the guide book?, (e) Check the guide book that already exist? Is there anything that is not useful? Contents as follows: (a) What themes and topics would like to be included in the guide book?, (b) How long is the guide book can be read?, (c) How should the guide book be used? Can people just read the relevant section or whether they need to read the guide book as a whole? Implementation as follows: (a) The extent to which the distribution area of the guide book?, (b) What type of layout you want (such as paper size, style graphic)?, (c) How the evaluation model?

\section{Conclusions}

The research results can be concluded as follows Microteaching Handbook for Lecturers, Student, Crew developed and declared properly use in the Science and Mathematic Faculty. Suggestions put forward in the research are as follows: (a) Teaching basic skills assessment instruments listed in the Handbook Microteaching, its should use the same scale range, (b) 
Need to include material about the wiring on Microteaching guide for crew in order to carry out the shooting and editing, (c) The Hand book Microteaching for Lecturer, Students, and Crew Learning Laboratory can be used in the next implementation of microteaching.

\section{References}

Brown, G. (1991). Pengajaran Mikro, Program Keterampilan Mengajar (alih bahasa Kaluge). Surabaya: Airlangga University Press.

Brown, G. (1975). Microteaching. A Programme of Teaching Skills. New York: Methuen \&Co. Ltd.

Fadullah, M.Y. (2012). Simulasi Model Pembelajaran untuk Meningkatkan Kemampuan Mahasiswa melakukan Program Pengalaman Lapangan. Retrieved from www.repository.upi.edu. diunduh pada 29 Desember 2012.

Fenrich, P. (1997). Practical Guidelines for Creating Instructional Multimedia Applications. Fort Worth, TX: Harcourt Brace

Gall, M.D., Gall, J.P., \& dan Borg, W.R. (2007). Educational Research: an Introduction. San Fransisco: Allyn and Bacon.

Muljono, Pudji. (2013). Kegiatan Penilaian Buku Teks Pelajaran Pendidikan Dasar Dan Menengah. $\quad$ Retrieved from http://repository.ipb.ac.id/bitstream/handle/123456789/33782/KPMpjm-artik5-kegiatan \%20penilaianpdf?sequence=1. Diakses tanggal 4 Maret 2013.

Sukmadimata, N.S. (2009). Metode Penelitian Pendidikan. Bandung: Rosdakarya

Sukirman, D. (2012). Pembelajaran Micro Teaching. Jakarta: Direktorat PAI Kementerian Agama

Suwarna, dkk. (2006). Pengajaran Mikro. Yogyakarta: Tiara Wacana

WRI. (2013). Kerjakan Sendiri: Membuat Buku Panduan. http://wri-irg.org/node/10944 diakses tanggal 3 Maret 2013

\section{Copyright Disclaimer}

Copyright reserved by the author(s).

This article is an open-access article distributed under the terms and conditions of the Creative Commons Attribution license (http://creativecommons.org/licenses/by/3.0/). 